\title{
Effects of exogenous polyamine and ultrasound treatment to improve peach storability
}

\author{
Erdinc Bal ${ }^{1}$
}

Peach (Prunus persica [L.] Batsch) is a perishable product and its storage period may be extended by using different postharvest methods. For this purpose, peaches harvested at the commercial ripening stage were treated with individual and combined effects of putrescine $(1 \mathrm{mM})$ and ultrasonic treatment $(32 \mathrm{kHz}$ for $10 \mathrm{~min})$; postharvest storage quality of peach fruit was evaluated during storage at $0-1{ }^{\circ} \mathrm{C}$ for $28 \mathrm{~d}$. Quality characteristics such as weight loss, fruit firmness, respiration rate, total sugar, total soluble solid content, titratable acidity, chilling injury, and decay rate were determined at the beginning and during the storage period at 1-wk intervals. The result showed that individual and combined effects of putrescine and ultrasonic treatment, when compared to control fruits, could increase peach fruit postharvest life by inducing resistance to different diseases and chilling injury with no noticeable effect on fruit quality attributes such as weight loss, total soluble solids, and total sugar. At the same time, a combined putrescine and ultrasound treatment was found to be more effective than other treatments in decreasing respiration rate and maintaining firmness and acidity. Peach storability could be extended with a combined putrescine and ultrasound treatment because it delays the ripening processes.

Key words: Chilling injury, Prunus persica, putrescine, quality, ultrasonic treatment.

\section{INTRODUCTION}

Peaches (Prunus persica [L.] Batsch) exhibit strong climacteric behavior and deteriorate quickly even at refrigerated temperature. Their storage life, contrary to other climacteric fruit (e.g., apples), rarely exceeds 4-5 wk, which makes these fruit types interesting for comparative physiological studies. Extended storage of peaches and nectarines induces a decrease of quality parameters (taste, texture), the appearance of chilling injury (CI), and physiological disorders such as woolliness (Lill et al., 1989; Lurie and Crisosto, 2005). Chilling injury is considered to be one of the most important symptoms affecting sensory characteristics in peaches; it is a physiological disorder affecting stone fruit stored for long periods in cold storage (Lurie and Crisosto, 2005).

Several conservation techniques have been used to extend the post-harvest life of perishable agricultural commodities. In many cases growers rely on alternative methods, including disinfectants or chemicals with low-residue thresholds, physical methods, controlled atmosphere, and biological control (Eshel et al., 2009).

Polyamines, generally putrescine (Put), spermidine (Spd), and spermine (Spm), are polycationic low molecular weight compounds present in living organisms

${ }^{1}$ Namik Kemal University, Agricultural Faculty, 59030 Tekirdag, Turkey. .Corresponding author (ebal@nku.edu.tr).

Received: 10 May 2013.

Accepted: 18 September 2013.

doi:10.4067/S0718-58392013000400016
(Galston and Sawhney, 1990). The use of exogenous polyamines to inhibit ethylene production and delay fruit ripening has been attempted (Perez-Vicente et al., 2002; Torrigiani et al., 2004). Polyamines are thought to prevent senescence by inhibiting the formation of enzymes that are essential to ethylene synthesis (Roberts et al., 1986; Ke and Romani, 1988). Reduced polyamine levels have been correlated with increased ethylene production (Kumar et al., 1996). Many studies have shown that exogenously applied polyamines affect fruit quality through some change in fruit firmness, weight loss, ethylene evolution, total soluble solids, and titratable acids (Khosroshahi et al., 2008). Exogenously applied Put reduced fruit deterioration and increaseed shelf life of lemon (Citrus limon [L.] Burm. f., Martínez-Romero et al., 1999), apricot (Prunus armeniaca L., MartínezRomero et al., 2002), sweet cherry (Prunus avium [L.] L., Bal, 2012), strawberry (Fragaria xananassa Duchesne ex Rozier, Khosroshahi et al., 2007), and plum (Prunus salicina Lindl., Perez-Vicente et al., 2002; Khan et al., 2008). Plums treated with $1 \mathrm{mM}$ Put showed delayed and reduced ethylene production together with higher fruit firmness, lower soluble solutions and titratable acids, reduced weight loss, and delayed color change, which led to extended storage life (Valero et al., 2002; Serrano et al., 2003).

Ultrasound (ultrasonic) is also one of the newest nonthermal methods to extend shelf life of fresh fruits during storage. When compared with other novel techniques, ultrasound technology is perceived to be safer, non-toxic, and environmentally friendly; it is assumed to be benign 
by the public because it is used in hospitals for diagnostic imaging purposes (Feng et al., 2010; Aday et al., 2012). Its frequency is generally above $20 \mathrm{kHz}$ and has mechanical, heat, and cavitation effects. High temperature and temperature variation, instant high pressure and pressure change produced by the effect of ultrasonic cavitation in liquid are used to kill some bacteria, inactivate viruses, or even damage the cell wall of some smaller microbials to extend fruit and vegetable storage time (Ji et al., 2012).

Knorr et al. (2004) reviewed improvements in direct food processing such as cleaning surfaces, enhancement of dewatering, drying and filtration, microorganism and enzyme inactivation, enzyme extraction, protein and antioxidant compounds, cell disruption, degassing of liquid food, and heat transfer acceleration. Though many studies have been done by applying ultrasound during food processing and preservation, there are few published reports on the effect of ultrasound treatments on postharvest horticultural physiology. In the studies, postharvest ultrasound treatments have been shown to extend shelf life and maintain quality in strawberries (Cao et al., 2010a; 2010b; Aday et al., 2012), litchis (Litchi chinensis Sonn., Chen et al., 2012), pears (Pyrus communis L., Zhao et al., 2007), and plums (Chen and Zhu, 2011). Yang et al. (2011) reported that a combined ultrasound and salicylic acid treatment may be a useful technique to reduce decay in peaches stored at $20{ }^{\circ} \mathrm{C}$. However, there are no reports on the effects of combined Put and ultrasound to improve peach storability. Therefore, the aim of our study was to investigate the efficacy of Put treatment and ultrasound used separately or combined on the postharvest quality of peaches stored at $0{ }^{\circ} \mathrm{C}$.

\section{MATERIALS AND METHODS}

Peaches (Prunus persica [L.] Batsch cv. Glohaven) used in our study were grown in Tekirdag (4059' N, 27²9' E) in the coastal region of the Marmara Sea, Turkey; they were harvested at the commercially mature stage, sorted to eliminate damaged and unripe fruit, and selected for uniform size and color.

Ultrasound treatment was applied in a water bath (20 ${ }^{\circ} \mathrm{C}$ ) in the ultrasonic chamber. Peaches were treated with $32 \mathrm{kHz}$ ultrasound at powers of $60 \mathrm{~W} \mathrm{~L}^{-1}$ for $10 \mathrm{~min}$ in 4 $\mathrm{L}$ distilled water. Based on a previous study (MartínezRomero et al., 2000), $1 \mathrm{mM}$ Put was chosen as the optimal concentration for our experiment.

Fruits were divided into four groups. The first group was immersed in distilled water at $20^{\circ} \mathrm{C}$ for $10 \mathrm{~min}$ (control); the second group was immersed in $1 \mathrm{mM}$ Put solution at $20{ }^{\circ} \mathrm{C}$ for $10 \mathrm{~min}$ (Put treatment); the third group was treated in an ultrasonic chamber at $20^{\circ} \mathrm{C}$ for $10 \mathrm{~min}$ (Ultrasound treatment); and the fourth group was treated with $1 \mathrm{mM}$ Put in the ultrasonic chamber at $20{ }^{\circ} \mathrm{C}$ for $10 \mathrm{~min}$ (Put+ultrasound). After treatments, fruits were removed from the bath and air-dried at $25^{\circ} \mathrm{C}$ for approximately $30 \mathrm{~min}$ (Cao et al., 2010b). Fruits were then placed in plastic boxes $(50 \times 30 \times 12 \mathrm{~cm})$ and stored at $0-1{ }^{\circ} \mathrm{C}$ and $85-90 \%$ relative humidity.

Samples were taken at the beginning of storage and at 7-d intervals during storage to analyze weight loss (\%), fruit firmness $(\mathrm{kg})$, respiration rate $\left(\mathrm{mg} \mathrm{kg}^{-1} \mathrm{~h}^{-1}\right)$, total sugar (g $\left.100 \mathrm{~g}^{-1}\right)$ (Ross, 1959), total soluble solid (TSS) content (\%), titratable acidity (as malic acid, TA) (\%), chilling injury $(\%)$, and decay rate $(\%)$. The respiratory rate, expressed in $\mathrm{mg} \mathrm{kg}^{-1} \mathrm{~h}^{-1}$ (Demirdoven and Batu, 2004), was determined by incubating $1 \mathrm{~kg}$ fruit of known mass and volume in a $7000 \mathrm{~mL}$ hermetic GENbox jar (bioMérieux SA, Marcy l'Etoile, France) for $1 \mathrm{~h}$ (at cold temperature, $0-1{ }^{\circ} \mathrm{C}$ ) and then determining $\mathrm{CO}_{2}$ concentration in the flask with a gas analyzer (Gaspace Advance GS3, Systech Instruments, Thanma Oxfordshire, UK).

\section{Statistical analysis}

Study data had a completely randomized design and were analyzed by ANOVA with two factors: treatments and time. Differences among treatment means were analyzed by the LSD test $(0.05 \%)$ and mean separation by MINITAB.

\section{RESULTS AND DISCUSSION}

\section{Weight loss}

Weight loss of peaches owing to moisture loss is also an important factor that determines fruit quality. Moisture loss during storage results in a peach with a shriveled and dry appearance, and symptoms are aggravated by increasing storage time and temperature (Nunes, 2008). Weight loss was increased by prolonging storage time (Figure 1); however, there were no significant differences between treatments at all determined times. These results agree with the findings of Yang et al. (2011) where salicylic acid, ultrasound, and the combination of both had

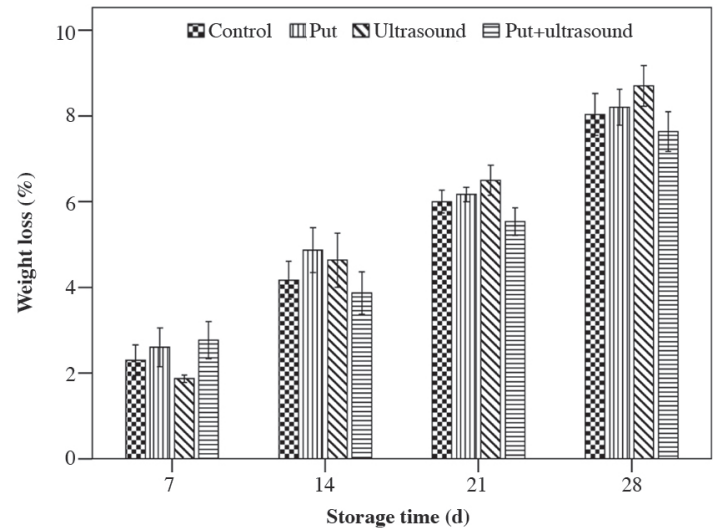

NS: Non significant. Vertical bars represent the standard error of the mean.

Figure 1. Effects of putrescine and ultrasound treatment on weight loss of peaches (treatments $\times$ days $\mathrm{LSD}_{0.05}=\mathrm{NS}$ ). 
no significant effect on weight loss of peaches after $6 \mathrm{~d}$ at $20^{\circ} \mathrm{C}$. At the end of the storage period, the highest weight loss was determined in ultrasound-treated fruits $(8.7 \%)$ and followed by Put (8.2\%). The lowest weight loss was observed in Put+ultrasound-treated fruits $(7.6 \%)$ and followed by control fruits (8.0\%). Weight loss findings in this study were not similar to those for apricot by MartínezRomero et al. (2002) and plum by Serrano et al. (2003), who found that Put showed significantly less weight loss as compared with untreated fruits. These different results may be explained by different physiological features of experimental materials and different storage conditions.

\section{Respiration rate}

A major factor contributing to postharvest losses is product respiration, which converts stored sugars or starch into energy in the presence of the $\mathrm{O}_{2}$ substrate and advances ripening (Day, 1990). Reduced respiration also retards softening and slows down various compositions, which are all changes associated with ripening (Kader, 1986). At the end of different storage periods, significant differences in respiration rate were found (Figure 2). Although fluctuations occurred in respiration rate, that is, increases and decreases, increases occurred in all the applications depending on the fruit ripening level at the end of storage time. The maximum respiration rate was seen from the fully ripe to overripe stage of peaches on the $28^{\text {th }}$ day. At the end of storage time, the highest peach respiration rate values was determined in control fruits (14.3 $\mathrm{mg} \mathrm{kg}^{-1} \mathrm{~h}^{-1}$ ), while the lowest respiration rate values were obtained in Put+ultrasound-treated fruits $(11.2 \mathrm{mg}$ $\mathrm{kg}^{-1} \mathrm{~h}^{-1}$ ). The slower respiration rate in Put+ultrasoundtreated fruits may be explained by slowing ripening through ultrasound action which increases Put penetration in fruits. This result agrees with previous studies where exogenous polyamines and ultrasound treatments decreased respiration rate of apricot (Martínez-Romero et al., 2002), kiwifruit (Actinidia deliciosa (A. Chev.) C.F.

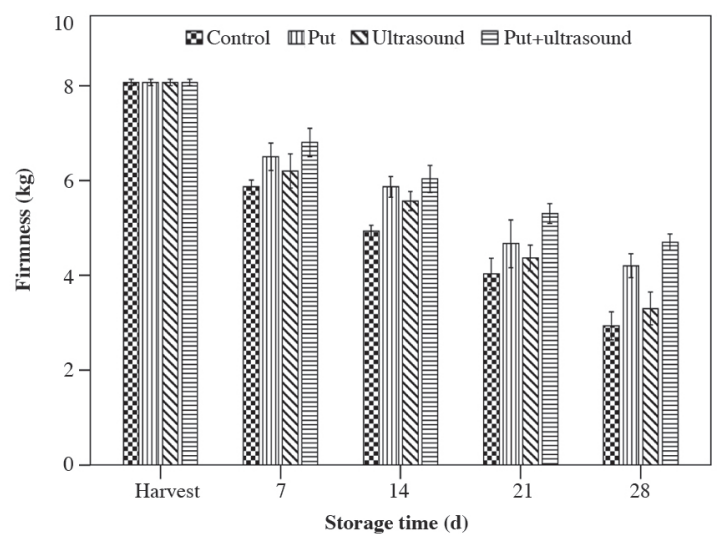

Vertical bars represent the standard error of the mean.

Figure 2. Effects of putrescine (Put) and ultrasound treatment on fruit firmness of peaches (treatments $\times$ days $\mathrm{LSD}_{0.05}=0.73$ ).
Liang \& A.R. Ferguson, Petkou et al., 2003), pear (Zhao et al., 2007), and plum (Chen and Zhu, 2011).

\section{Fruit firmness}

Peaches are climacteric fruit; they can be harvested when they are still firm but physiologically mature, which means they will continue to ripen after harvest and during the storage period. Loss of fruit firmness as the storage period progresses is mainly due to decomposition and enzymatic degradation of insoluble protopectins to more simple soluble pectins (Abd El-Migid, 1986). In the present study, fruit firmness of peaches was significant with interaction effects between treatments and storage periods (Figure 3). There was a continuous decline in fruit firmness during storage. The decreases in Put- and Put+ultrasound-treated fruits were less than in ultrasoundtreated and control fruits. The highest firmness value was detected in fruits dipped in Put+ultrasound treated fruits $(4.7 \mathrm{~kg})$ and then in Put-treated fruits $(4.2 \mathrm{~kg})$ at the end of storage. This finding corroborates Khosroshahi et al. (2007), who reported that one of the main effects of polyamines during fruit and vegetable postharvest life is to maintain their flesh firmness and delay the ripening processes. Treatments with exogenous PAs (polyamines) have been shown to increase flesh firmness in several fruits, including 'Golden Delicious' and 'McIntosh' apples (Malus domestica Borkh., Kramer et al., 1991), lemons (Martínez-Romero et al., 1999), plums (Perez-Vicente et al., 2002), peaches (Bregoli et al., 2002), and sweet cherries (Khosroshahi et al., 2008). However, ultrasound treatment was not as effective as the Put treatment to maintain fruit firmness.

\section{Total sugar}

The edible quality of peaches and nectarines depends to a great extent on sweetness, which is related to total sugar content. The total sugar content value varied between

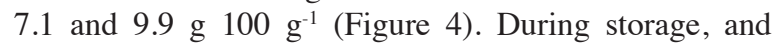

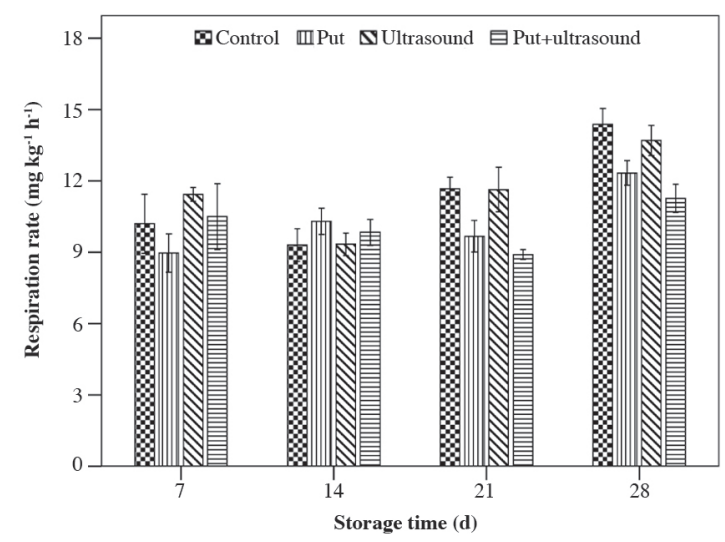

Vertical bars represent the standard error of the mean.

Figure 3. Effects of putrescine (Put) and ultrasound treatment on respiration rate of peaches (treatments $\times$ days $\mathrm{LSD}_{0.05}=2.20$ ). 


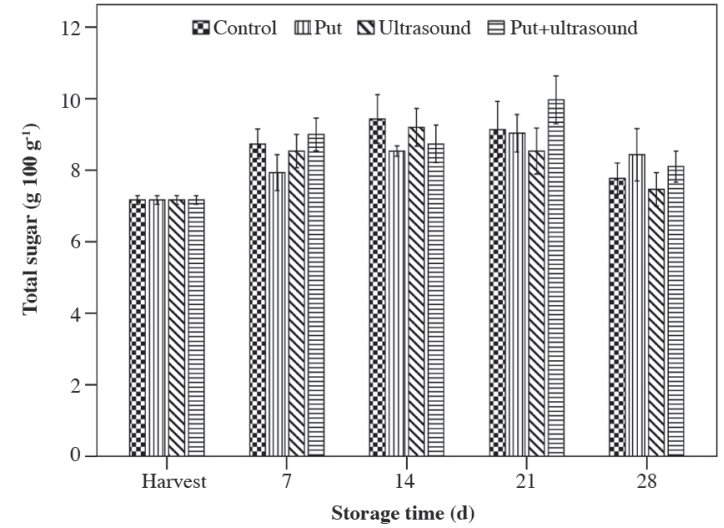

NS: Non significant. Vertical bars represent the standard error of the mean.

Figure 4. Effects of putrescine (Put) and ultrasound treatment on total sugar of peaches (treatments $\times$ days $\mathrm{LSD}_{0.05}=\mathrm{NS}$ ).

depending on treatments, total sugar content initially increased but declined afterward. Increased total sugar levels are possibly due to enhanced fruit ripening and senescence. However, there was no significant difference of sugar content among all treatments. After $28 \mathrm{~d}$ of storage, the lowest sugar content was determined in the

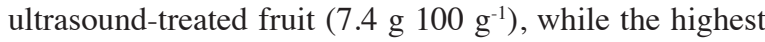
sugar content was determined in Put-treated fruit $(8.4 \mathrm{~g}$ $\left.100 \mathrm{~g}^{-1}\right)$. This may be because Put treatments reduced losses by minimizing total sugar contents degradation of peaches. Bhagwan et al. (2000) and Malik et al. (2003) also reported that postharvest Put application preserved sugar in tomatoes (Lycopersicon esculentum Mill.) and mangoes (Mangifera indica L.) when compared with the control.

\section{Total soluble solids}

Total soluble solids (TSS) increased as the fruit approached maturity regardless of the treatment during the storage period as a result of insoluble starches being converted into soluble solids. The present study has clearly indicated that TSS in peaches would increase throughout the storage period. The interaction effects between treatments and storage period for TSS were not significant (Figure 5). At the beginning of storage, TSS of peaches was $11.5 \%$. The highest TSS content in the trials was determined in the control application at the end of storage $(14.3 \%)$, while the lowest TSS values were determined in the Put treatment $(10.7 \%)$ on the $7^{\text {th }}$ day. These results are in accordance with the finding by Khan et al. (2008), Khosroshahi and Ashari (2008), and Bal (2012), who reported that Put-treated fruit stored at low temperatures exhibited lower soluble solid content than untreated fruits.

\section{Titratable acidity}

Organic acids are minor components in peaches, but they significantly contribute to organoleptic quality combined

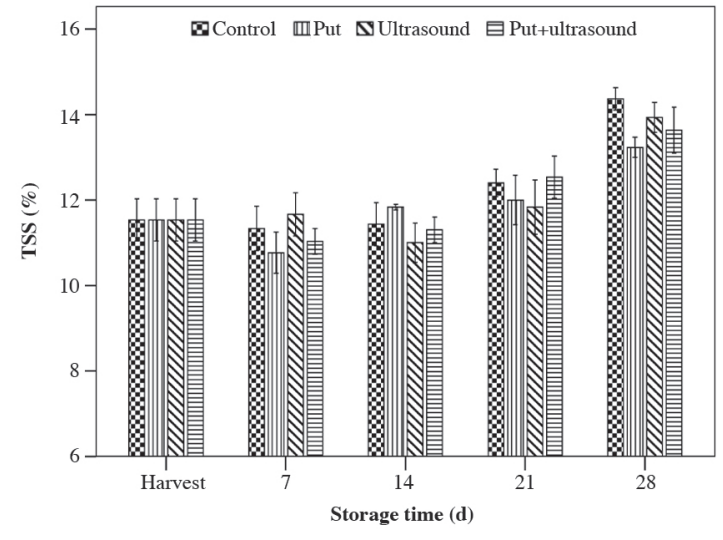

NS: Non significant. Vertical bars represent standard error of the mean.

Figure 5. Effects of putrescine (Put) and ultrasound treatment on total soluble solids $($ TSS $)$ of peaches (treatments $\times$ days $\mathrm{LSD}_{0.05}=\mathrm{NS}$ ).

with sugar and aromatic compounds (Wang, 1993). In the current study, TA of peaches was $0.79 \%$ at the beginning of storage. Depending on the treatments, TA of peaches decreased progressively with extended storage (Figure 6). The decrease in TA at the end of storage might be due to the metabolic changes in fruits or could be due to the use of organic acid in the respiratory process. A significant difference was found in TA among treatments. On the $28^{\text {th }}$ day, while the highest TA content of peaches was detected in Put+ultrasound-treated fruits $(0.65 \%)$, the lowest TA content was determined in ultrasound-treated fruits $(0.56 \%)$. Liu et al. (2006) reported that the reasons remain unclear why PAs modify soluble solutions and titratable acids. Cao et al. (2010a) and Yang et al. (2011) also informed that ultrasound treatment had no significant effect on TA.

\section{Chilling injury}

Chilling injuries in peaches and nectarines can induce

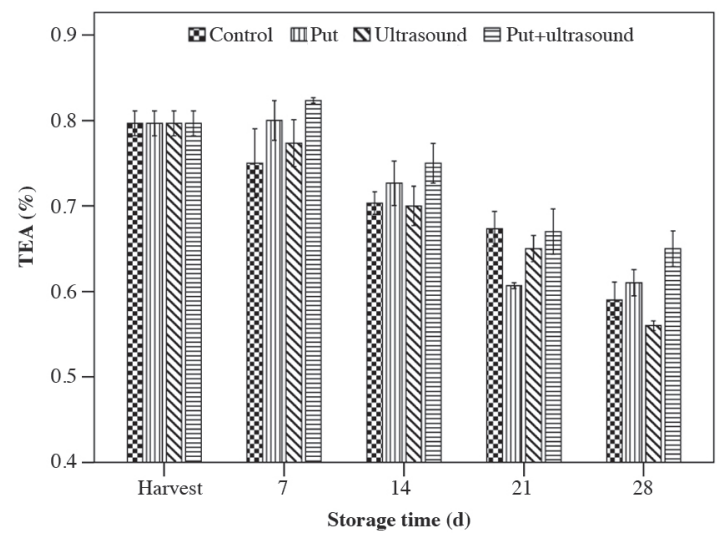

NS: Non significant. Vertical bars represent the standard error of the mean.

Figure 6. Effects of putrescine (Put) and ultrasound treatment on titratable acidity of peaches (treatments $\times$ days $\mathrm{LSD}_{0.05}=\mathrm{NS}$ ). 
different symptoms, including mealiness or lack of juice, flesh browning, and impaired softening, which is referred to as leatheriness. Visible CI symptoms develop within 1 or $2 \mathrm{wk}$ when peaches are stored at $2-5^{\circ} \mathrm{C}$ as compared with 3 or more wk at $0{ }^{\circ} \mathrm{C}$ (Lurie and Crisosto, 2005). In the present study, CI symptoms first appeared in control peaches after 3 wk of storage with a minor appearance of leatheriness and browning.

Chilling injury symptoms, measured as browning of the skin and internal breakdown, were significantly diminished by the Put+ultrasound treatment (Figure 7). At the end of storage, CI symptoms were not seen in Put+ultrasound-treated fruits. This result indicates that the ultrasound treatment could raise Put activity against CI. The highest CI values were also determined in control fruits $(10.4 \%)$. Polyamine biosynthesis has been reported to alter various kinds of stress including CI (Malik et al., 2003). Chilling injury symptoms in mangoes have been observed to be associated with the biosynthesis of PAs (Nair and Singh, 2004). Postharvest dip application of PAs has been reported to inhibit CI in apricot (Koushesh et al., 2012), mango (Nair and Singh, 2004), and zucchini squash (Cucurbita pepo L., Wang, 1993).

\section{Decay rate}

The present results indicated that the mean percentage fruit decay markedly increased with an increasing storage period (Figure 8). Significant differences $(\mathrm{p}<0.05)$ were found among treatments. Until $3 \mathrm{wk}$ after treatments no decay symptom was observed on fruits except for control fruits $(2.9 \%)$. However, decay incidence subsequently began to develop and reached a maximum level in control fruits $(13.3 \%)$ at the end of storage. No decay symptom in Put+ultrasound-treated fruits was determined during the storage period. On the $28^{\text {th }}$ day, the decay rate for ultrasound-treated fruits was $8.8 \%$ and $3.9 \%$ for Puttreated fruits. Our research corroborates several studies that have shown that Put and ultrasound treatment can

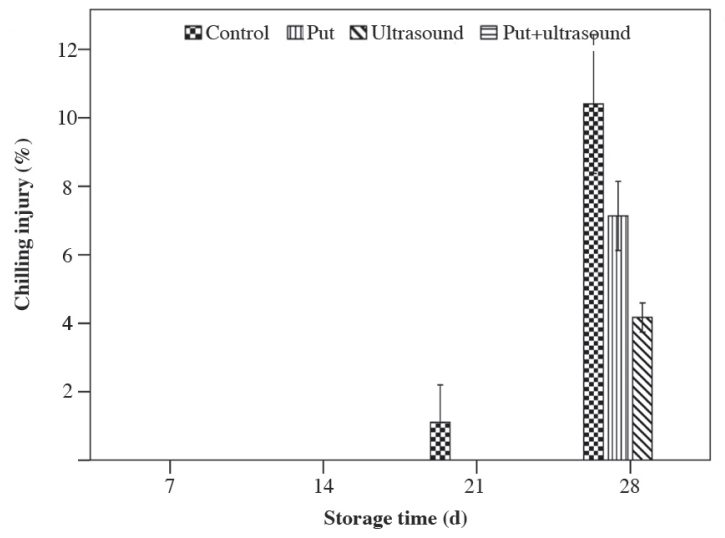

Vertical bars represent the standard error of the mean.

Figure 7. Effects of putrescine (Put) and ultrasound treatment on chilling injury in peaches (treatments $\times$ days $\mathrm{LSD}_{0.05}=1.83$ ).

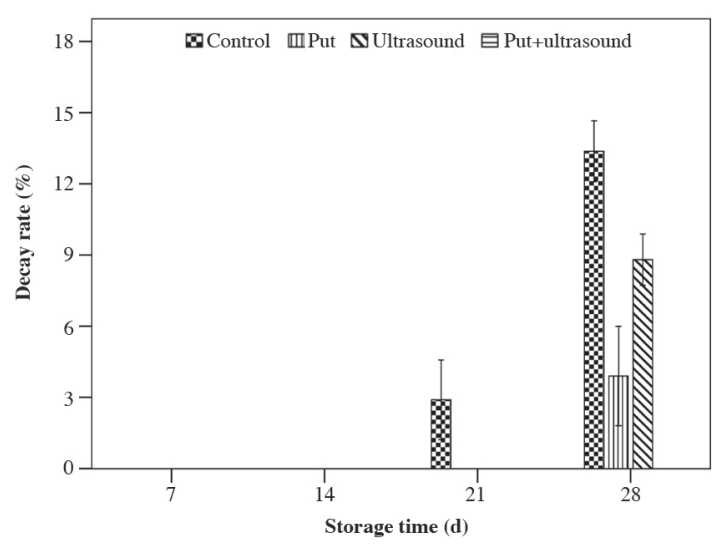

Vertical bars represent the standard error of the mean.

Figure 8. Effects of putrescine (Put) and ultrasound treatment on decay rate of peaches (treatments $\times$ days $\mathrm{LSD}_{0.05}=2.27$ ).

control postharvest diseases in fruits (Chen and Zhu, 2011; Yang et al., 2011; Bal, 2012; Aday et al., 2012). Used separately, the Put treatment was effective in inhibiting decay of peaches. Cao et al. (2010a; 2010b) reported that ultrasound treatment is highly effective to inactivate microorganisms, but applying ultrasound treatment alone had less influence on fungal decay development than the Put treatment. Celik et al. (2006) reported that CI increased susceptibility of fruit to fungal growth which developed on chill-injured fruits. Similar results have been found in the present study.

\section{CONCLUSIONS}

In conclusion, the present study shows that a combined putrescine and ultrasound treatment was more effective to control chilling injury and decaying than either treatment alone. The Put+ultrasound treatment could delay the ripening process by inhibiting respiration rate in peaches. This treatment can be easily used instead of laborious postharvest treatments to improve peach quality and storability.

\section{LITERATURE CITED}

Abd El-Migid, M.B. 1986. Post-harvest physiological studies on Le conte and Kiefer pear fruits stored at different temperatures. PhD Thesis. Alexandria University, Alexandria, Egypt.

Aday, M.S., R. Temizkan, M.B. Buyukcan, and C. Caner. 2012. An innovative technique for extending shelf life of strawberry: Ultrasound. LWT - Food Science Technology 52:93-101.

Bal, E. 2012. Effect of postharvest putrescine and salicylic acid treatments on cold storage duration and quality of sweet cherries. Suleyman Demirel University Journal of the Faculty of Agriculture 7:23-31.

Bhagwan, A., Y.N. Reddy, and P.V. Rao. 2000. Postharvest application of polyamines to improve the shelf-life of tomato fruit. Indian Journal of Horticulture 57:133-138.

Bregoli, A.M., S. Scaramagli, G. Costa, E. Sabatini, V. Ziosi, S. Biondi, et al. 2002. Peach (Prunus persica) fruit ripening: aminoethoxyvinylglycine (AVG) and exogenous polyamines affect ethylene emission and flesh firmness. Physiologia Plantarum 114:472-481. 
Cao, S., Z. Hu, and B. Pang. 2010b. Optimization of postharvest ultrasonic treatment of strawberry fruit. Postharvest Biology and Technology 55:150-153.

Cao, S., Z. Hu, B. Pang, H. Wang, H. Xie, and F. Wu. 2010a. Effect of ultrasound treatment on fruit decay and quality maintenance in strawberry after harvest. Food Control 21:529-532.

Celik, M., A.E. Ozdemir, and E. Erturk. 2006. Changes in some quality parameters of the perfect delight nectarine cultivar during cold storage and shelf life. Turkish Journal of Agriculture Forestry 30:253-260.

Chen, Y., Y. Jiang, S. Yang, E. Yang, B. Yang, and K.N. Prasad. 2012. Effects of ultrasonic treatment on pericarp browning of postharvest litchi fruit. Journal of Food Biochemistry 36:613-620.

Chen, Z., and C. Zhu. 2011. Combined effects of aqueous chlorine dioxide and ultrasonic treatments on postharvest storage quality of plum fruit (Prunus salicina L.) Postharvest Biology and Technology 61:117-123.

Day, B. 1990. MAP of selected prepared fruits and vegetables. $p$. 230-233. In Zeuthen, P. (ed.) Processing and quality of foods. Vol 3. Chilled foods and the revolution in freshness. Elsevier, London, UK.

Demirdoven, A., and A. Batu. 2004. Respiration rates of some important fruits grown in Tokat. GTED 17:33-37.

Eshel, D., R. Regev, J. Orenstein, S. Droby, and S. Gan-Mor. 2009. Combining physical, chemical and biological methods for synergistic control of postharvest diseases: A case study of Black Root Rot of carrot. Postharvest Biology and Technology 54:48-52.

Feng, H., G.V. Barbosa, and J. Weiss. 2010. Ultrasound technologies for food and bioprocessing. Springer, New York, USA.

Galston, A.W., and R.K. Sawhney. 1990. Polyamines in plant physiology. Plant Physiology 94:406-410.

Ji, L., J. Pang, S. Li, B. Xiong, and L.G. Cai. 2012. Application of new physical storage technology in fruit and vegetable industry. African Journal Biotechnology 11:6718-6722.

Kader, A.A. 1986. Biochemical and physiological basis for effects of controlled and modified atmospheres on fruits and vegetables. Food Technology 40:99-104

Ke, D., and R.J. Romani. 1988. Effects of spermidine on ethylene production and the senescence of suspension-cultured pear fruit cells. Plant Physiology Biochemistry 26:109-116.

Khan, A.S., Z. Singh, N.A. Abbasi, and E.E. Swinny. 2008. Pre or post-harvest applications of putrescine and low temperature storage affect fruit ripening and quality of 'Angelino' plum. Journal of the Science of Food and Agriculture 88:1686-1695.

Khosroshahi, M.R.Z., and E.M. Ashari. 2008. Effect of putrescine application on post-harvest life and physiology of strawberry, apricot, peach and sweet cherry fruits. Journal of Science and Technology of Agriculture and Natural Resources 45:219-230.

Khosroshahi, M.R.Z., E.M. Ashari, and M. Fattahi. 2008. Effect of exogenous putrescine on postharvest of sweet cherry fruit, cultivar 'Surati-e Hamedan'. Journal of Applied Horticulture 10:154-157.

Khosroshahi, M.R.Z., M. Esna-Ashari, and A. Ershadi. 2007. Effect of exogenous putrescine on postharvest life of strawberry (Fragaria ananassa Duch.) fruit, cultivar Selva. Scientia Horticulturae 114:27-32.

Knorr, D., M. Zenker, V. Heinz, and D. Lee. 2004. Applications and potential of ultrasonics in food processing. Trends in Food Science and Technology 15:261-266.

Koushesh, M., K. Arzani, and M. Barzegar. 2012. Postharvest polyamine application alleviates chilling injury and affects apricot storage ability. Journal of Agricultural and Food Chemistry 60:8947-8453

Kramer, G.F., C.Y. Wang, and W.S. Conway. 1991. Inhibition of softening by polyamine application in 'Golden Delicious' and 'McIntosh' apples. Journal of the American Society for Horticultural Science 116:813-817.

Kumar, A., M.A. Taylor, S.A. Arif, and H.V. Davies. 1996. Potato plants expressing antisense and sense S-adenosylmethionine decarboxylase (SAMDC) transgenes show altered levels of polyamines and ethylene: antisense plants display abnormal phenotypes. The Plant Journal 9:147-58.
Lill, R.E., E.M. O’Donaghue, and G.A. King. 1989. Postharvest physiology of peaches and nectarines. Horticulture Review $11: 413-452$

Liu, J.H., C. Honda, and T. Moriguchi. 2006. Involvement of polyamine in floral and fruit development. Japan Agricultural Research Quarterly 40:51-58.

Lurie, S., and C.H. Crisosto. 2005. Chilling injury in peach and nectarine. Postharvest Biology and Technology 37:195-208.

Malik, A.U., Z. Sing, and S.S. Dhaliwal. 2003. Exogenous application of putrescine affects mango fruit quality and shelf life. Acta Horticulturae 628:121-127.

Martínez-Romero, D., D. Valero, M. Serrano, F. Burló, A. Carbonell, L. Burgos, et al. 2000. Exogenous polyamines and gibberellic acid effects on peach (Prunus persica L.) storability improvement. Journal of Food Science 65:288-294.

Martínez-Romero, D., D. Valero, M. Serrano, and F. Riquelme. 1999. Effects of post-harvest putrescine and calcium treatments on reducing mechanical damage and polyamines and $\mathrm{ABA}$ level during lemon storage. Journal of the Science of Food and Agriculture 79:1589-1595.

Martínez-Romero, D., M. Serrano, A. Carbonell, O.L. Burgos, F. Riquelme, and D. Valero. 2002. Effect of postharvest putrescine treatment on extending shelf life and reducing mechanical damage in apricot. Journal of the Science of Food and Agriculture 67:1706-1712.

Nair, S., and Z. Singh. 2004. Chilling injury in mango fruit in relation to biosynthesis of free polyamines. The Journal of Horticultural Science and Biotechnology 79:515-522.

Nunes, M.C.N. 2008. Color atlas of postharvest quality of fruits and vegetables. 463 p. In M.C.N. Nunes (ed.) Wiley-Blackwel Publishing, Ames, Iowa, USA.

Perez-Vicente, A., D. Martínez-Romero, A. Carbonell, M. Serrano, F. Riquelme, F. Guillen, et al. 2002. Role of polyamines in extending shelf life and the reduction of mechanical damage during plum (Prunus salicina Lindl.) storage. Postharvest Biology and Technology 25:25-32.

Petkou, I., T. Pritsa, and E. Sfakiotakis. 2003. Effect of dipping and pressure infiltration of putrescine on the propylene induced autocatalytic ethylene production and ripening of 'Hayward' kiwi fruit. Acta Horticulturae 610:261-266.

Roberts, D.R., E.B. Dumbroff, and J.E. Thompson. 1986. Exogenous polyamines alter membrane fluidity in bean leaves - a basis for potential misinterpretation of their physiological role. Planta 167:395-401.

Ross, A.F. 1959. Dinitrophenol method for reducing sugar. p. 469470. In Talburt, W.F., and O. Smith (ed.) Potato processing. Avi Publishing Company, Westport, Connecticut, USA.

Serrano, M., D. Martinez-Romero, F. Guillén, and D. Valero, 2003. Effects of exogenous putrescine on improving shelf life of four plum cultivars. Postharvest Biology and Technology 30:259-271.

Torrigiani, P., A.M. Bregoli, V. Ziosi, S. Scaramagli, T. Ciriaci, A. Rasori, et al. 2004. Pre-harvest polyamine and aminoethoxyvinylglycine (AVG) applications modulate fruit ripening in Stark Red Gold nectarines (Prunus persica L. Batsch). Postharvest Biology and Technology 33:293-308.

Valero, D., A. Pérez-Vicente, D. Martínez-Romero, S. Castillo, F. Guillén, and M. Serrano. 2002. Plum storability improved after calcium and heat postharvest treatments: role of polyamines. Journal of Food Science 67:2571-2575.

Wang, C.Y. 1993. Relation of chilling stress to polyamines in zucchini squash. Acta Horticulturae 343:288-289.

Yang, Z.F., S.F. Cao, Y.T. Cai, and Y.H. Zheng. 2011 . Combination of salicylic acid and ultrasound to control postharvest blue mold caused by Penicillium expansum in peach fruit. Innovative Food Science and Emerging Technologies 12:310-314.

Zhao, Y., Z. Feng, and X. Li. 2007. Effect of ultrasonic and MA packaging method on quality and some physiological changes of fragrant pear. Journal of Xinjiang Agricultural University 30:6163. 